\title{
The Absence of Legal Recognition and Its Impact on The Living Conditions of Urban Pakistani Refugees in Bangkok
}

Jesper Kulvmann

Department of Social and Development, Thammasat University, Thailand

\begin{abstract}
Recently, an increasing number of refugees originating from non-neighbouring countries have arrived in Bangkok seeking asylum at UNHCR. As Thailand does not recognize their refugee status and by so their human rights guaranteed in the Declarations of Human Rights, this group of people, referred to as urban refugees, remain in Bangkok illegally during the application process and until possible resettlement. This study examines how restrictions of their human rights, such as absent of fear of arrest, right to work and access to welfare provisions, and a prolonged application process affect the physical and mental health of urban refugees. Data are gathered from semi-structured interviews of 53 Pakistani refugees and officers at organisations working with refugees. Depression and declining physical health are common complains while refugee children fail to enrol in formal education. Considering the lack of support for a human rights dialogue in the Thai society it is recommended that a more pragmatic approach, not employing a human rights narrative, is applied to promote the living conditions for urban refugees living in Bangkok.
\end{abstract}

Keywords: Urban Refugees, Human Rights, Legal Status, Health, Formal Education, \& Agency.

\section{INTRODUCTION}

Globally, the current international refugee crisis has tested nations' commitment to international treaties that protect refugees. The offering of refuge within the framework of human rights increasingly collides with arguments concerning national security and the protection of the welfare of the host nations' citizens. Today, most refugees flee to countries, which they may not necessarily perceive as safe, but which they are forced to enter. The majority enters as asylum seekers, who will have to prove their need of asylum before they may qualify for permanent protection of the host country and obtain refugee status. The uncertainty of the faith of asylum seekers is even more perturbing in countries that do not recognize people's right to apply for asylum. In these countries refugees may approach regional offices of the United Nations High Commissioner for Refugees (UNHCR) to obtain UN refugee status that entitles the refuges to resettlement in a third country. In such an environment the safety of the refugees is not secured by national law, but rather by the commitment of governments to observe Human Rights. This is the situation in Thailand and most ASEAN countries. In these countries the asylum seekers have officially status of undocumented immigrants. Most refugees with an illegal status live in designated refugee camps, but a growing number lives outside those confinements and they are referred to as urban refugees. ${ }^{1}$ Due to their undocumented status they are living as disenfranchised noncitizens and in fear of the authorities.

Traditionally, the abuse of human rights of asylum seekers are addressed within three different frameworks: persecution in the state of origin; rights violations in the course of

1 By definition, urban refugee, refers to the geographical space of the asylum seeker/refugee and not to their legal status. The term is commonly used in countries, which operate refugee camps. 
migration; and abusive host practices at the point of reception.. ${ }^{2}$ This article purely concentrates on the latter situation, investigating the living conditions of Pakistani urban UNHCR asylum seekers and recognized refugees in Bangkok. Within the framework of human rights, the article sets out to demonstrate how the denial of the rights of asylum and lack of protection against arbitrary arrest affect Pakistani refugees' human rights to work and to access health provision and basic education for their children.

The article relies on a study of Pakistani refugees residing in Bangkok and officers at organizations working with refugees. Prior to the presentation of this study, the relationship between human rights and the 1951 Declaration of Refugees and the refugee situation in Thailand will be discussed. In this study," refugee" is used as a composite term referring to all refugees, irrespective of whether their application for asylum is pending, accepted or ejected by UNHCR.

\section{Human rights and the 1951 Refugee convention}

Refugee and human rights regimes have developed congruently. Hence, refugee law provisions should be seen within the configuration of human right laws ${ }^{3}$. In the wake of WWII, UNHCR was created with a mandate to protect refugees. UNHCR's activities were founded on a framework of international law and standards that included the 1948 Universal Declaration of Human Rights and the fourth Geneva Convention. ${ }^{4}$ However, at the time there were concerns about the entitlement of human rights and "the legal status of persons who do not enjoy the protection of any government" 5 . That instigated the formulation of the 1951 Refugee Convention (Refugee Convention) and later the 1967 Protocol Relating to the Status of Refugees (1967 Protocol). The refugee Convention and the 1967 Protocol have since formed the foundation of international law and they cover three main subjects: The basic refugee definition, the legal status of refugees in their country of asylum, including refoulment, and the obligations of and the cooperation between contracting states and UNHCR ${ }^{6}$. Art. 33(1) in the Refugee Convention stipulates that non-refoulment refers to the obligation of States not to return a refugee "against his or her will, in any manner whatsoever, to a territory where he or she feels threats to life or freedom". ${ }^{7}$ Today, non-refoulment is universally acknowledged as a human right. ${ }^{8}$

According to The Refugee Convention, Art. $1 \mathrm{~A}(2)$, 'refugee' is defined as "someone who is unable or unwilling to return to their country of origin owing to a well-founded fear of being persecuted for reasons of race, religion, nationality, membership of a particular social group, or political opinion". ${ }^{9}$ Globally, the definition is recognized for the purpose of humanitarian assistance. ${ }^{10}$ Based on article 14 of the Universal Declaration of Human Rights, the Refugee

2 J. Bhabha," Internationalist Gatekeepers? The tension Between Asylum Advocacy and Human Rights", 15, Harvard Human Rights Fournal 155 at 156.

3 K. Jastram; M. Achiron, Refugee Protection: A Guide to International Refugee Law (Office of the United Nations High Commissioner for Refugees, Geneva: Switzerland, 2001).

4 Jastram et al, supra note 3.

5 G. Jaeger," Opening Keynote Address: The Refugee Convention at Fifty" in J.V. Selm et al (eds) The Refugee Convention at Fifty (US: Lexington Books, 2003) at 11.

6 D. Kugelmann, "Refugees", 2010, Oxford Public International law, Max Planck Encyclopedia of Public International Law; 1. Jaeger, supra note 5.

7 UNHCR, Convention and Protocol, Relating to the Status of Refugees, http://www.unhcr.org/enus/protection/basic/3b66c2aa10/convention-protocol-relating-status-refugees.html (2010) at 3 .

8 International Justice Resource Center (IJRG), Asylum and the Rights of Refugees, http://www.ijrcenter.org/refugee-law (2017)

$9 \quad$ UNHCR, supra note 7.

10 Kugelmann, supra note 6. 
Convention recognizes the right of persons to seek asylum on grounds within the parameters of the notion "refugee". Signatories to the Refugee Convention must consider an application for asylum by any foreign national or stateless person presenting himself at the time of entrance to a foreign country. However, the convention does not spell out how States should determine refugee status. An asylum seeker may be denied asylum, but under international refugee law the State must provide subsidiary protection for persons in a refugee-like situation.

Therefore, states are disinclined to respect the obligations and recognize the right of asylum as an individual right. States are facing a dilemma welcoming refugees: on the one hand they want to provide relief, on the other hand they do not want them to stay long. ${ }^{11} \mathrm{In}$ different terms, asylum can be described as a limited humanitarian safety valve, permitting only a fraction of would-be-immigrants. Asylum as such functions as a "bridge between morality and law" 12 in the sense that it upholds a gatekeeping function protecting the primacy of sovereign state borders while the process of asylum eligibility justifies migration exclusion. ${ }^{13}$ Hannah Arendt ${ }^{14}$ writes that "although the right to asylum had continued to exist in a world organized into national states......it is still felt to be an anachronism and a principle incompatible with the international laws of the State". Within that perspective, states feel that they may legitimately question whether asylum seekers enjoy any kind of convention status during the provisional asylum period before they are granted refugee status. ${ }^{15}$ With the dramatic global increase of refugees applying for asylum, governments and the public disassociate themselves from the humanitarian mission of offering security and protection. International solidarity is challenged, and states and international humanitarian organizations argue about "burden sharing" and "responsibility sharing". ${ }^{16}$

In this environment, the advocacy of the protection of refugees appears more pertinent than ever. Today, the asylum advocacy is closely linked with the discursive strategies from the human rights agenda. The Universal Declaration of Human Rights are heavily entangled with the Refugee Convention, granting refugees rights to free movement, to education and health provision and non-discriminatory access to social assistance and employment. ${ }^{17}$ Over the years specialized human rights instruments have been put in place protecting human rights of specific social groups, such a child. The Convention of the rights of the Child ${ }^{18}$, applies to all children, including refuge children. ${ }^{19}$

\section{The refugee situation in Thailand}

In line with most ASEAN countries, Thailand is not a signatory to the Refugee Convention or the 1967 protocol $^{20}$. The main argument brought forward for not accepting these institutions is the claim that they are "Eurocentric"; a burden brought on developing countries and therefore irrelevant to their experiences. ${ }^{21}$ Thailand considers refugees to be migrants with sans papier or "clandestine", persons who have entered the country illegally or who have

\footnotetext{
11 N. Murshid, The Politics of Refugees in South Asia: Identity, Resistence, Manipulation (Abingdon: Routledge. 2014)

12 D. Held," Laws of States, Laws of Peoples: Three Models of Sovereignty", 8:1, Legal Theory 1.

13 Bhabha, supra note 2.

14 H. Arendt, The Origins of Totalitarianism, (London: George Allen and Unwin Ltd., 1967) at 280

15 Jaeger, supra note 5.

16 J.V. Selm, Global Solidarity: Report of a Plenary Session in F.V. Selm, et al (eds) The Refugee Convention at Fifty, (US: Lexington Books, 2003).

17 Bhabha, supra note 2.

18 Thailand is a signatory of the Convention.

19 Jastram et al, supra note 3.

20 Only the Philippines and Cambodia have signed the Refugee Convention.

21 S.E. Davies, International Refugee Law in South East Asia, (Boston: Martinus Nijhoff. 2008)
} 
overstayed their visum and with no legal status under national or international law. ${ }^{22}$ The 1979 Immigration Act states that all undocumented immigrants are aliens (illegal) and subject to deportation. However, UNHCR and the Thai government have made an informal agreement, that urban refugees registered with UNHCR, can stay in Thailand until their case is closed. Nevertheless, many urban refugees are detained.

However, the Refugee Convention's stipulation of non-refoulment is generally reckoned by refugee law scholars to be binding to all states as customary international law. ${ }^{23}$ Helton $^{24}$ claims that the principle of non-refoulment also requires states to provide "temporary asylum under humane and tolerable living conditions". This means that Thailand, though it has not signed the Refugee Convention, is obliged not to refoul refugees to states where they may face cruel or degrading treatment. ${ }^{25}$ In the past, Thailand has expatriated Burmese refugees, but it does not deport refugees from non-bordering countries.

Thailand is also morally bound by the human rights documents it has ratified. Though Thailand has signed the UN Declaration of Human Rights it is critical of the universality of the Declaration. As a signatory to the Declaration of the ASEAN Human Right Declaration (AHRD) it employs a more particularistic view of Human Rights. Still, the ASEAN Declaration clearly stipulates that "every person has the right to seek and receive asylum in another state in accordance with the laws of such state and applicable international agreements", AHRD, art.16. Articles 12, 27, 28 and 29 ensure that every person should not be the subject of arbitrary arrest or detention and that every person has the right to work and to obtain an adequate standard of living. Affordable health care and primary education should also be available for all ${ }^{26}$. However, Thailand's policies on refugees do not correspond with the words of the ASEAN Declaration of Human rights.

Regardless of whether applications for asylum are pending, rejected or accepted by UNHCR, refugees in Thailand are "de facto refugees", meaning that they remain within the state of Thailand without any formal recognition. Though the Refugee Convention does not mention de-facto refugees, some provisions of the Refugee Convention do cover them, and they should still enjoy human rights. ${ }^{27}$ However, those human rights do not necessarily include the right to work. ${ }^{28}$ It is noteworthy, that in recent years many Western countries have steadily introduced more restrictive measures limiting the right for asylum seekers to work. ${ }^{29}$ The lack of a legal framework has left urban refugees in Thailand in a precarious state, very vulnerable to arbitrary arrest and exploitation in the labour market and without any formal

22 Kugelmann at 17 , supra see note 6.

23 A. Helton," Asylum and Refugee Protection in Thailand, 1989, 1:1, International Fournal of Refugee Law, 1:1, p. 20; E. Lauterpacht, E., D. Bethlehem, The Scope and Content of the Principle of Non-refoulement in E. Feller, F. Nicholson (eds), Refugee Protection in International Law, UNCHR's Global Consultation on International Protection, (Cambridge: Cambridge University Press, 2003).

24 Ibid., at 40.

25 L. Collewet," Inhumane Detention Conditions in Bangkok?" 2:1, 2012, Oxford Monitor of Forced Migration 544.

26 ASEAN," ASEAN Human Rights Declaration, and the Phnom Penh Statement on the application of the ASEAN Human Rights Declaration", The ASEAN Secretariat, http://www.asean.org/storage/images/ASEAN_RTK_2014/6_AHRD_Booklet.pdf, 2013.

27 Kugelmann, supra note 6.

28 Ibid.

29 M. Gower, should asylum seekers have unrestricted rights to work in the UK? Briefing Paper 1908, ( London: House of Commons Library, 2016); I. Bray, When can asylum applicants get a work permit, http://www.nolo.com/legalencyclopedia/asylum-applicants-work-permit-timing-32297.html, 2017; V. Germany V, Working in Germany: getting a German Work Permit, Germany-visa.org/working-germany-getting-german-work-permit, 2017; Ministry of Immigration and Integration 2016, "Aliens (Consolidation) Act of 25th. of June 2013" in New to Denmark, Ministry of Integration and Immigration (Denmark), https://www.nyidanmark.dk/en-US/ 
access to legal assistance. Still, out of fear of expulsion no human right cases involving refugees have been brought forward in Thailand. ${ }^{30}$

Nonetheless, over the past decades Thailand has received millions of refugees. Most refugees in Thailand are from Myanmar, see table 1. They are restricted to live in 9 designated camps along the Thai-Burmese border and they have no freedom to move or work. They register with UNHCR ${ }^{31}$, but formally they remain illegal immigrants in Thailand.

\begin{tabular}{|l|l|l|}
\hline \multicolumn{3}{|l|}{ Table 1: UNHCR figures on asylum seekers and refugees, December 2015.} \\
\hline Type of population & Origin & Total in country, \\
\hline \multirow{3}{*}{ Refugees } & Sri Lanka & 500 \\
\cline { 2 - 3 } & Myanmar & 53,600 \\
\cline { 2 - 3 } & Pakistan & 700 \\
\cline { 2 - 3 } & Various & 2,600 \\
\hline \multirow{2}{*}{ People in refugee-like situations } & Myanmar & 32,600 \\
\cline { 2 - 3 } & Various & 1,000 \\
\hline Asylum seekers & Palestinian & 1,300 \\
\cline { 2 - 3 } & Pakistan & 11,500 \\
\cline { 2 - 3 } & Various & 4,100 \\
\hline Stateless & Stateless & 506,200 \\
\hline Total & & 614,100 \\
\hline
\end{tabular}

In recent years an increasing number of urban refugees have arrived in Thailand from nonneighbouring countries. They fly into Bangkok on a tourist visum and register for asylum at the UNHCR in Bangkok, applying for resettlement in a third country. Thailand is a popular destination for registering with UNHCR as it is very easy to obtain a tourist visum. Countries of origin of asylum seekers and refugees registering with UNHCR include: Pakistan, Palestine, Syria, Sri Lanka, Vietnam, Somalia, Iran, China Cambodia, Iraq, Democratic Republic of Congo and Egypt. ${ }^{32}$ Pakistanis are the biggest group, see table 1. It must be noted that by 2017 the numbers of Pakistanis are significantly reduced, see below.

\section{Status of Pakistani refugees in Bangkok}

Pakistanis are fleeing their country due to religious persecution. Officially, Christianity is legal to practice and protected by law. Still, Christians (Protestants and Catholics) complain that they are severely discriminated and at times exposed to death threats. Members of the Ahmadiyya Muslim community flee Pakistan as their faith is viewed to be heretical and hence forbidden to practice. Christians make up 90\% of the Pakistani community in Bangkok.

On arrival in Bangkok, it may take months to register with UNHCR. Once registered, asylum seekers may wait for several years for a "Refugee Status Determination" (RDS) interview. ${ }^{33}$ It is not uncommon that interviews are postponed, and interviewees may wait for more than 6 months for the outcome of an interview. Declined applications can be appealed. $90 \%$ of Ahmadis obtain refugee status while 90\% of Christian Pakistanis have their application rejected ${ }^{34}$. Within the last year, UNHCR has speeded up the RDS process. This

30 Human Rights Watch, Ad Hoc and Inadequate. Thailand's Treatment of refugees and Asylum Seekers, Human Rights Watch, US. https://www.hrw.org/sites/default/files/reports/thailand0912.pdf, 2012.

31 Since 2012, UNHCR has been denied registering new arrivals of refugees in the camps.

32 Urban refugees Organisation, Bangkok, Thailand, http://urban-refugees.org/bangkok/, 2015.

33 ibid.

34 Unofficial data. 
has resulted in a sudden increase in number of registered refugees and equally many rejections of applications, leading to a dramatic decrease in the number of UNHCR registered asylum seekers in Bangkok. By June 2017, it is estimated that there are about 3500 UNHCR registered asylum seekers and 3000 UNHCR registered refugees in Bangkok. ${ }^{35}$ 90\% are from Pakistan. But due to the current international refugee crisis, European and North American countries have severely reduced their acceptance of quota refugees. Acknowledged UNHCR refugees will most likely have to wait for years to be resettled. During this period, they remain illegal immigrants in Thailand. Those who have their asylum application rejected drop out of the UNHCR registration, and it is unknown how many return to their home country or remain in Bangkok, persevering as de-facto refugees with an illegal status.

\section{METHOD}

This paper is based on a survey containing interviews with 53 Pakistani refugees living in Bangkok and three persons working for two NGOs, respectively Asylum Access Thailand (AAT) and BPSOS, ${ }^{36}$ and a faith organisation helping refugees in Bangkok. ${ }^{37}$ In the paper, the officers of the organisations are referred to as "officers". The focus is on Pakistani refugees, as they are estimated to account for nearly $90 \%$ of all urban refugees living in Bangkok. The interviews were conducted between March 2016 and June 2017. The identities of all interviewees will remain confidential for ethical and security reasons.

A sample of respondents was constructed with the assistance of community leaders. The researcher stratified the sample according to location, faith, gender and age. The sample contained 32 males and 21 female respondents. It included two teenagers aged 16 years, 10 respondents from 18 to 24, 24 were between 25 to 39, 13 were between 40 - 55 and 3 were in their late fifties. 32 interviewees were Christians, 19 were Ahmadies and 2 young participants were Shia Muslims. Two Christians had gained refugee status by UNHCR, while 4 Ahmadis had not gained such status. The two Shia Muslims had status of asylum seekers. It was solely the community leaders who recruited participants. As such they operated as gatekeepers, which is a shortcoming of the sample that the researcher is much aware of.

Interviews included questions on income, employment, housing, access to health provision, health status, uptake of formal education by their children and family life. The interviews were not based on any formalized hypothesis and as such the study had an inductive character.

Participants were interviewed individually. They lasted in average approximately 45 minutes. However, due to poor accommodation of the respondents, interviews taking place in their flats were at times carried out with the presence of other family members. 25 of the interviews of refugees were conducted in English, while 28 were conducted in Urdu and through a Pakistani translator.

It must be noted that the validity and reliability of the interviews come into question. This is a common phenomenon interviewing undocumented immigrants ${ }^{38}$. Interviewees have a strong interest in promoting their need and justify their claim for assistance. Information on

35 There are no proper data on the number of urban refugees by country in Thailand. UNHCR hesitates to publicize the figures. Asylum Access Thailand (AAT) estimates that by June 2017, 7600 asylum seekers and refugees are registered with UNHCR in Bangkok.

36 Asylum Access Thailand provides legal counsel and representation to refugees seeking asylum in status determination proceedings by UNHCR. BPSOS is an American organization that works on refugee protection (legal advice) and society development.

37 The organisation wanted to remain anonymous.

38 W.A. Cornelius," Interviewing Undocumented Immigrants: Methodological Reflections Based on Fieldwork in Mexico and the U.S.”, 1982, 16:2, The International Migration Review, Special issue: Theory and Methods in Migration and Ethnic Research 378. 
income or personal assets were often set so low that it did not add up. Therefore, interviews focused less on actual size of income but more on how a presumed limited budget affected their health status and education of their children.

At the time of writing this article, it has not been possible to establish interviews with UNHCR and Bangkok Refugee Centre, the main NGO in Bangkok assisting refugees. However, the interviewed officers worked exclusively with urban refugees. It must be stressed that they represent themselves and not the organization they work for.

Findings

The presentation of the findings will within a human rights framework concentrate on how the very insecure position of Pakistani refugees affect their everyday life. Initially, findings will be presented on how the fear of house raids and arbitrary arrest by the police deters refugees from any activities outside their homes and influence their choice of accommodation. This will be followed by a presentation of the respondents' accounts of their economic situation and employment conditions, access to health care and their children's and young people's participation in formal and informal education.

\section{Arrests}

The Thai government practices a punitive detention policy towards refugees. Hence, they live with the constant risk of being arrested. People are regularly stopped in the streets, or the police raids apartment blocks where a high number of refugees reside. In September 2015, the police raided an apartment block and arrested 64 asylum seekers, including 7 children ${ }^{39}$.

The policy of arbitrary arrest is in breach of article 31 of the Refuge Convention, as it stipulates that "refugees should not be penalised for illegal entry or presence, and [the article] has been interpreted as meaning that the detention of asylum seekers shall only be used when it is necessary, reasonable, and proportionate to the objectives pursued" ${ }^{40}$ But as Thailand is a non-signatory, it is not compelled to apply the obligation.

Bribes are commonly demanded for not bringing undocumented persons to Bangkok's Immigration Detention Centre (IDC), where people can remain in detention for indefinite years. Payments are determined on a sliding scale based on a person's ability to pay. ${ }^{41}$ Arrested or detained persons can be granted bail at the cost of 50.000 baht, guaranteed by a Thai national. ${ }^{42}$ Out of 53 participants in the sample, four were on bail. Six interviewees had a family member (husband, wife, brother) in the Detention Centre. Nine men had experienced being stopped or arrested by the police. Bribes of 3000 - 4000 baht were generally paid to avoid being sent to the detention Centre. A father of 3 had been arrested in the street:

"They stopped me right outside the house... we went to my flat and I paid them 3000 baht. I called my friends and they helped me. Ever since I have been afraid of going out...now, I do not sleep well".

Housing Conditions

All Pakistani interviewees lived in apartment blocks spread around Bangkok, and as such appears to be a very dispersed group, which is a common feature of urban refugee communities. ${ }^{43}$

39 Human Rights Watch, supra note 30.

40 L. Collewet," Inhumane Detention Conditions in Bangkok?", 2012, 2:1 Oxford Monitor of Forced Migration 1 at 2.

41 Human Rights Watch, supra note 30.

42 Urban Refugees Organisation, supra note 32.

43 P. Marfleet, P.,"” Forgotten"," Hidden": Predicaments of the Urban Refugee", 2007, 24:1 Urban Refugees 36. 
Previously, it has been described how urban refugee are in poor areas of the city. ${ }^{44}$ That was not the case of the interviewees, and the officers confirmed that this finding reflects the housing situation of urban refugees in Bangkok. However, the accommodation is of a poor standard. All interviewees, except three, rented together with their family one-room apartments, approximately 14-16 $\mathrm{m}^{2}$, with an adjacent bathroom, which usually contains a non-flushing toilet and a water tap, but no zink or shower. A small balcony serves as the kitchen comprising a propane burner. The room is typically furnished with one big bed, one or two extra madrassas, a fridge and cupboards and containers for storing clothes etc. Hardly any households have a television, but most have a computer. A typical household includes a married couple, 3 to 4 children aged 0 to early 20 s, and at times other family members.

Until recently, most Pakistani refugees would live in apartment blocks holding many Pakistani families. Police raids on these estates have been common, and as a result many families have moved into buildings mostly occupied by Thai nationals. A married woman, aged 30, with three children said:

"We have moved twice, because the places were raided by the police.... there are only 2 other Pakistani families [present residence]. It is better now... The landlady knows the police. We feel safer now".

Hardly any Pakistani refugees, though most of them had lived in Bangkok for at least three years, spoke Thai. They have extremely limited social interaction with Thai nationals, but no interviewees reported having had any problems with their Thai neighbours or Thais in general. Considering that refugees may spend many years in Bangkok, the officers perceived the lack of integration into the Thai society as a major problem of the Pakistani refugees. Commonly, the only time a Christian family would leave their room together was on Sundays going to church. Apart from a few teenagers, no youngsters or children socialized with their Thai peers. In fear of the police, children were held inside the building, and most often inside their room in order not to cause any noise and consequently complaints from Thai neighbours. The very basic right of a child to play ${ }^{45}$ was clearly absent. A mother of three children said:

"It is an open prison. I have to keep the children in the room all day. They never get out to play.... I'm afraid to go out. I only speak with my neighbours, but we respect each other's privacy and we stay in our rooms".

With families spending the entire day within the confinement of an overcrowded room, much stress is imposed on individuals. While some respondents said that their hardship had made them grow closer to their wife or husband, the majority of married interviewees reported that they argue much more with their spouse about peripheral issues and that their insecure situation puts a strain on their marriage. Particularly the male refugees noted that the difficulties upholding a physical relationship was very frustrating. Respondents were not asked if they had experienced any forms of violence within their family. But, Angela Burnett et $\mathrm{al}^{46}$ write that refugee women are particularly vulnerable to domestic violence as they may lack family and community support, and within the last two years Asylum Access Thailand confirmed that they have dealt with 35 cases of domestic violence.

44 V.D. Otter, V.D.," Urban Asylum Seekers and Refugees in Thailand”, 2007, 28 Forced Migration Review 49.

45 Article 31 of The Convention on the Rights of the Child says: "States Parties recognize the right of the child to rest and leisure, to engage in play and recreational activities appropriate to the age of the child and to participate freely in cultural life and the arts" (United Nations Human Rights, 2017)

46 A. Burnett; M. Peel, M.," Health needs of asylum seekers and refugees", 2001, 322:7285, British Medical Journal 544 . 
Household income

With no right to work, refugees are compelled to depend on own savings or funds received from other family members or friends, assistance from NGOs or to work illegally in underpaid jobs. They become victims who are forced to rely on charity, underlining their marginalized position in the society.

Except medical costs ${ }^{47}$, UNHGR does not provide any financial support. Equally, the resources of the NGOs or faith organization are sparse, and they limit their assistance to handouts of food. However, some Christian congregations support families financially. Initially, respondents' account of how they made ends meet, did not add up. Those who held a job would typically earn about $6000-7000$ baht, which is estimated to be insufficient to cover the living costs of a family of five to six members. As rapport between interviewer and respondents grew, it transpired that almost all had relied, at least for the first couple of years in Bangkok, on personal savings. Later on, the refugees would receive funds from family members in Pakistan, North America or Europe. It was important for all interviewees to point out that they had had a financially secure life in Pakistan. Now, several male interviewees expressed a feeling of humiliation because they felt responsible for the poor living conditions of their family. A father of two children aged 8 and 6 commented:

"My boy asks me why he cannot have this and that...when he used to have it back home. It is very hard not to be able to buy him normal things. Sometimes I feel I let him down".

(translated)

No statistical material exists on the matter, but two officers believed that an increasing, but still small number of refugees are involved in criminal activities, including prostitution. The need to cover urgent medical costs is one factor that drives people into taking drastic measures to generate an income.

\section{Employment}

The denial of legal employment leaves the far majority of asylum seekers in material deprivation, but it also comprises other social and mental ramifications. Numerous studies demonstrate that unemployment has a negative effect on psychological wellbeing, including self-esteem ${ }^{48}$. Jenny Phillimore et $\mathrm{al}^{49}$ demonstrate in a study in the UK of asylum seekers with skills and qualifications that lack of employment exacerbates the general levels of social exclusion. Other studies ${ }^{50}$ confirm that those who enter the illegal labour market in Thailand generally experience severe exploitation in terms of low payment, long working hours and employment in "3D jobs". Particularly the Pakistani men verified these findings.

Most male interviewees had at some stage held either casual or more permanent jobs, while only a handful of women had held a job. The employment of women was restricted to

47 UNHCR does not directly cover medical costs. However, Bangkok Refugee Centre receives funds from UNHCR to cover such costs.

48 I. Theodossiou," The effects of Low-pay and unemployment on psychological well-being: A logistic regression approach", 1998, 1, Fournal of Health Economics 85; E. Latif," Crisis, unemployment and psychological wellbeing in Canada", 2010, 32:4, Fournal of Policy Modelling 520.

49 J. Phillomore, L. Goodson," Problem or Opportunity? Asylum Seekers, refugees, employment and Social Exclusion in Deprived Urban Areas", 2006, 43:10, Urban Studies 1715.

50 M. Green, K. Jacobsen," Invisible in Thailand: documenting the need for protection", 2008, 30, Forced Migration Review 31; A. Derks, "Human Rights and (Im)mobility: Migrants and the State in Thailand", 2013, 28:2, Journal of Social Issues in Southeast Asia, 216. 
rather safe working environments, such as volunteer teachers at learning centres, see below, interpreters for NGOs or participation in handicraft projects organized by a faith organization. Most families upheld a traditional division of work with the husband being the main breadwinner.

Those men who did not work cited fear of arrest or "bail" as the main reasons for not working. They did not dare to break the bail, knowing that they would be sent to IDC if they were caught working. Men working as casual workers at construction sites had experienced not being paid. Permanent jobs included working as watchmen or as chefs at Indian or Pakistani restaurants. Generally, people would work 10-12 hours a day, often 7 days a week. Most interviewees would not complain about these working conditions, but rather express some kind of appreciation that they had a chance to work. Equally, they generally accepted their low payment, as their employers took a risk hiring them. It seemed common that a restaurant owner bribed the police in order to protect his undocumented employee. A man in his forties working at an Indian restaurant earning about 6500 baht a month revealed:

"The police came to the restaurant once. The owner paid the police"....

On the question whether the low payment was fair, the interviewee shrugged his shoulders and responded:

\section{"He [employer] takes a chance and pay the bribes"}

Access to health services and health status

Refugees are not entitled to any free treatment at government hospitals ${ }^{51}$. Apart from emergency situation it is up to the discrepancy of a government hospital to see undocumented patients on a pay for service basis. Bangkok Refugee Centre (BRG) covers expenses related to pregnancy and treatment of children up to the age of 5. Refugees will only be reimbursed minimal amounts on a case to case basis, and full coverage will only be offered for the treatment of life-threatening conditions. On the last Sunday of the month, in a public park in Bangkok, the Tzu Chi foundation ${ }^{52}$ offers free consultations with nurses and doctors. The clinic also provides free medication for some chronic diseases, but surgical procedures are not available.

\section{Mental Health}

General health of asylum seekers is reported in multiple surveys to be critical ${ }^{53}$. Customarily, refugees are believed to have been subject to traumatic episodes, both physical and psychological violence, before arrival at the host county. Refugees have often experienced violent conflicts, at times torture and lengthy and difficult courses of escape ${ }^{54}$. Post-traumatic Strees Disorder (PTSD) and depression are common clinical diagnoses obtained by refugees. However, exile-related stress factors are also critical for the physical and mental health of asylum seekers. ${ }^{55}$ The Canadian Task Force on Mental Health Issues (1998) lists a number of

51 Thailand offers free basic universal health care for all citizens. More advanced treatment is not covered free of charge. About $30 \%$ of the working force in Thailand has some kind of social insurance that according to size of the premium covers medical expenses not covered by the universal scheme.

52 A Taiwanese organization setting up free basic health services for vulnerable groups. According to its website it operates in 69 countries (Tzu Chi Mission, 2009)

53 A.M. Gerritsen, I. Bramsen, I., W. Deville, L.H.M. Willigen, J.E. Hovern, H.M. Ploeg,” Physical and mental health of Afghan, Iranian and Somali asylums seekers and refugees living in the Netherlands", 2006, 41:1, Social Psychiatry and Psychiatric Epidemiology" 18.

54 Z. Steel, M. Hey, D. Silove et al," Association of Torture and other Traumatic Events with Mental Health Outcomes among Populations Exposed to Mass Conflict and Displacement, A systematic review and Meteanalysis"., 2009, 302:5, 7AMA 537.

55 R. Pernice, J. Brook," Refugees' and immigrants' mental health: association of demographic and posttraumatic factors", 1996, 136, Fournal of Social Psychology 511. 
factors, such as; separation from family and community: an unwelcoming community, being elderly or adolescent, not speaking the local language and loss of socio-economic status. ${ }^{56}$ Unemployment and financial difficulties have also been documented in several surveys to cause distress. ${ }^{57}$ Laban et $\mathrm{al}^{58}$ document in a survey of Iraqi asylum seekers in the Netherlands, that social isolation and a long asylum procedure seems to be associated with psychiatric disorders and Tribe ${ }^{59}$ (2002) points out that social isolation and poverty have a negative impact on mental health.

This survey is based on respondents' self-reported assessment of their health status. This study does not investigate why people have fled their country. Therefore, the study does not set out to examine any specific relationship between possible level of persecution in home country and current health problems. It is beyond the scope of this study, and the capability of the researcher, to discuss possible PTSD with interviewees. In the survey respondents were in very general terms asked to describe their mental health status and current determinants. However, no interviewees listed torture or physical violence as reasons for fleeing Pakistan. But, several interviewees claimed that they had received death threats.

The far majority of adults, and some teenagers, complained that they suffer from depression due to exile-related stress factors. ${ }^{60}$ Few reported that they received any counselling or medical treatment for this condition. They mostly cited their poor situation, not being able to provide for their children, their fear of arrest, the feeling of lack of understanding by the authorities, mainly UNHCR, and the long waiting time and insecurity about their future. A woman with 3 children, and a family member at the detention centre, had waited for nearly 4 years to know her status: ${ }^{61}$

"Why do they [UNHCR] keep us waiting. They do not respect us... We had to leave because our lives were in danger. They do not understand us... they do not listen to us. I had an interview in October. I still haven't heard anything.

One girl, in her late teens, had openly blamed her father for the miserable life she endured. She had been in treatment for depression, but she still did not support his decision to leave Pakistan. Her father explained with the daughter being present:

"I brought her here because of my work, that makes me feel guilty. ... She got depressed and we went to BRC and saw [a] psychiatrist and she told him: I'm like this because of my father... The psychiatrist told me to say sorry to my girl and after that she was OK. But sometimes she still loses her mind again and she starts fighting with me and three to four times she has dropped her small DVD like this - on the floor".

Physical Health

The physical health of the adult population was generally assessed to be poor. The far majority of interviewers above the age of 20 were overweight ${ }^{62}$ and interviewees confirmed that they had gained considerable weight, many 7-10 kilos during their stay in Bangkok. The majority of interviewees above 40 suffered from diabetes and hypertension. This

56 R. Tribe," Mental Health of refugees and asylum-seekers", 2002, 8:4, Advance in Psychiatric Treatment 240.

57 Theodossiou \& latif, supra see note 48; D. Silove, Z. Steel, C. Watters," Policies of Deterrence and the Mental Health of Asylum Seekers", 2000, 284:5, Journal of American Medical Association 604.

58 C. Laban, H. Gernaat, I. Komproe, B. Schreuders, J. Jong," Impact of a long Asylum Procedure on the Prevalence of psychiatric Disorder in Iraqi Asylum Seekers in the Netherlands", 2004, 192:12, The Fournal of Nervous and Mental Disease 843.

59 Tribe, supra see note 56.

60 Pernice et al, supra see note 55.

61 Interview March 2017.

62 This assessment was made purely on an observational basis. 
finding confirms a study by Amara \& Alijunid, ${ }^{63}$ that the most common health concerns for urban refugees in the global South are hypertension and diabetes. Those suffering from chronic diseases mainly relied on medication handed out at the monthly Tzu Thi clinic.

A very sedentary life style and possibly a poor diet emerge as the most likely determinants of their poor physical health status. Some women complained that they did not have enough money to buy vegetables and fruit, but that they relied more on cheaper food categories, which hold more fats and sugar. However, all interviewees recognized that their personal health status was closely linked to being physical inactive. Still, hardly any exercised, using lack of space and danger to move in the public as excuses. There were exemptions, such as a couple that would go for a walk in the local park every morning before everybody else got up. They viewed this routine as important for maintaining their physical and mental health.

Children and pregnant women were the most common groups in need of hospital treatment. Generally, women felt that they are treated well at Thai government hospitals and none reported that they had felt discriminated because of status or linguistic barriers, which Vittaporn ${ }^{64}$ otherwise reports are common obstacles for Burmese migrant workers. People 's complaints were overwhelming related to lack of funds covering their medical expenses. This left many families having to ask friends or family to help them out or simply forego treatment. A father of 3 children complained:

"When I had money in my pocket I could get treatment... But now my child is in need and I do not have money in my pocket... for two years I have not even bought them new shoes" ... Once my son got seriously ill. I took him to the hospital [government] and the charged me 1600 baht. I only had 600 baht... After some time, I got help from my friends". (translated)

Education

Thai law stipulates, that all children, regardless of their legal status and nationality, have the right to 12 years of free basic education. ${ }^{65}$ Hardly any knowledge exists on the uptake of formal education by children in a refugee situation. ${ }^{66}$ For refugee children, three options of schooling are offered: Thai Government School, Learning Centres and private schooling.

Out of 28 households with school aged children ${ }^{67}$ only two families had sent their children to a Thai school. The main reason for not sending a child to a Thai school was fear of arrest travelling to and from school. Other parents did not trust the local environment. A mother of one child, who did not attend any educational institution, stated:

You hear many things, and the children learn bad manners... Children are cruel, and they will mob my son because he is Pakistani.

A child must pass a basic Thai test in order to enrol in a Thai government school, but few children have obtained the sufficient language skills to do so. RBC offers Thai courses, but a minority of children takes up the offer, partly because of the problem of travelling.

Local communities organize learning centres, where the children are taught in Urdu, but with much emphasis on learning English in preparation for their "new life" in a resettled country. Learning Centres appeared to be the main source of education for Pakistani

63 A.H. Amara, S.M. Aljunid, "Noncommunicable diseases among urban refugees and asylum-seekers in developing countries: a neglected health care need", 2004, 10:24, Globalization and Health.

64 S.Vittaporn, P.Boonmongkon, "Thailand's health screening policy and screening of Burmese migrants with tuberculosis", 2016, 37:3, Kasetsart Fournal of Social Sciences 170.

65 Government Gazette," National Education Act of B.E. 2542 (1999)", 1999, 116:74a, The Government Gazette, http://thailaws.com/law/t_laws/tlaw0165a.pdf.

66 Save the Children, Pathways to a Better Future: A Review of Education for Migrant Children in Thailand, 2014, Save the Children in Thailand, Bangkok.

67 The age of the children of 3 respondents are not known. 
children. Still, many teens did not attend learning centres. The learning centres are not formally recognized, and the students do not receive any accreditation. This severely limits the future option of education or employment of the students. ${ }^{68}$

Some children attended a private low fee school run by a charity organization. This school had two major assets. It runs a transport service between the school and the homes of the students, and it teaches in English. It was clear that the parents also disregarded the Thai school, because they did not find it beneficial to learn Thai.

Parents of those children who did not attend a formal school acknowledged that their children missed out developing normal social relationships with their peers. But, as families perceive their stay in Bangkok in a transitional perspective, the argument did not resonate with them. However, a mother (Ahmadi), of five children (husband living in Pakistan) and with minimum education herself, had sent her 3 school aged children to a Thai public school. Today, the children speak Thai. The mother explained:

I did not get a good education myself and I have felt I did not do well in life.... I was living in Bang Keng [area in Bangkok]. When I was living there I used to take my children to school. We left at 5 o'clock in the morning.... it lasted 6 months. We would reach home at 8 o'clock at night. After that we got admission at a Thai government school... I'm not thinking about food or security. Our most serious problem is lack of education. (translated)

Several young people had left Pakistan while they were at university. Naturally, they felt frustrated that they couldn't continue their education in Thailand, but at the same time they felt assured that they would be able to make up for lost time when they resettle in their new country. Not only the youngsters, but also the parents appeared to rest their hopes on the possibilities opening up when they resettle. However, many of their children will have lost out on formal education for up to six to seven years, perhaps even longer, before resettlement. It appears, that many of the refugees did not fully comprehend the disadvantage position their children will face in the resettled countries.

Resume of findings

This study demonstrates how the lack of legal protection deprives a group of urban refugees the right to uphold a socially and economically secure life. The fear of arrest affects their ability to earn a living legally, but it also has an impact on housing pattern, family life and the schooling of their children. The insecurity coupled with the uncertainty of their future causes high stress levels leading to mental health problems. A very sedentary life style aggravates their poor physical health status and the living conditions of the refugees cause serious health problems. See figure 1. 
Figure 1: relationship between factors affecting dimensions of living conditions of Pakistani urban refugees.

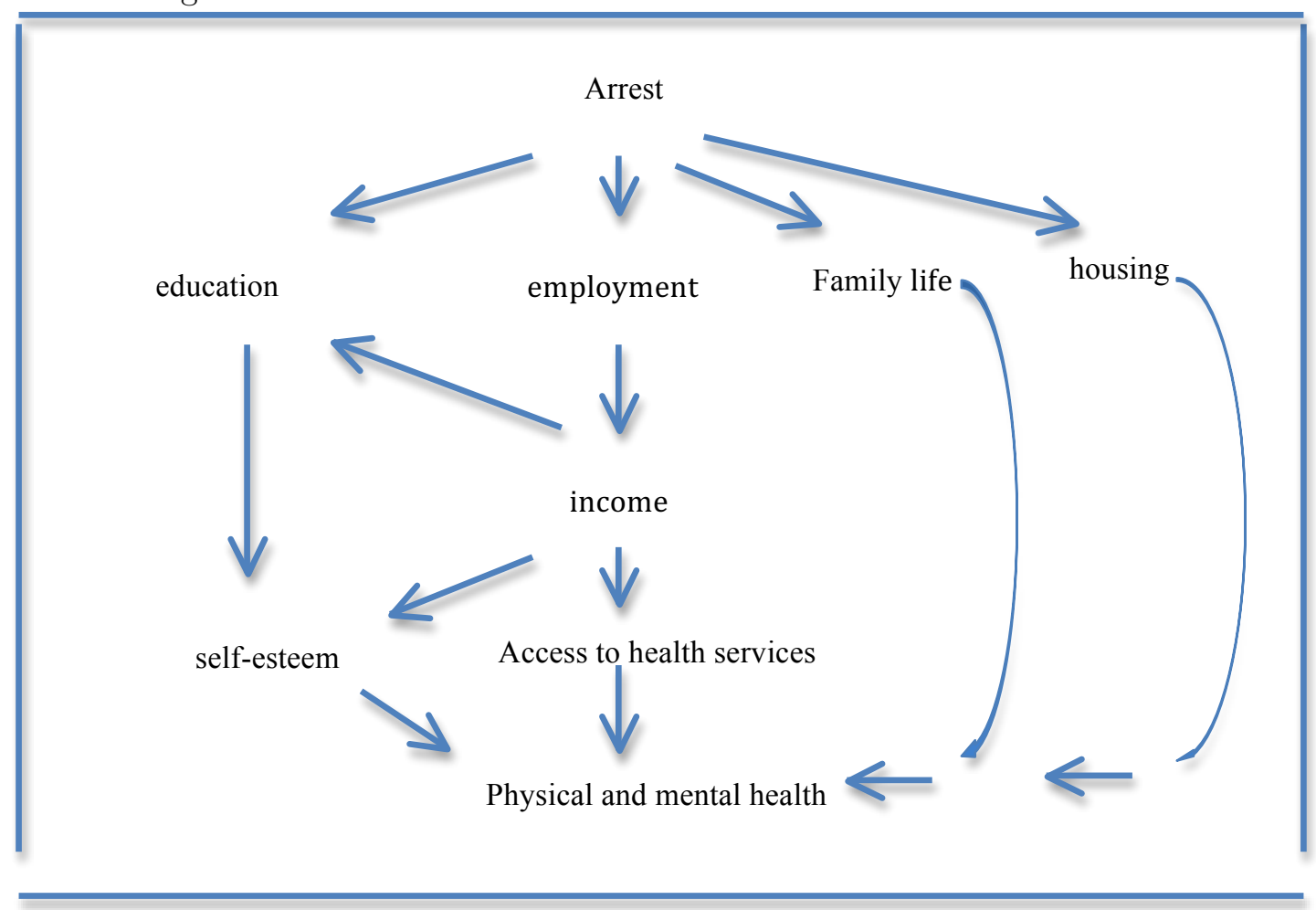

A major concern is also the lack of formal education for children and young people. They are very isolated from the Thai society and by so deprived of social stimuli that are important in formative years. Overall, the urban refugees are very disconnected from the Thai society and left to rely on charity. This exacerbates their social situation as victims.

\section{DISGUSSION}

Keeping the escalating international refugee crisis in mind and the apparent contest among nations to redefine the rights of asylum seekers into their most narrow interpretations, the international community has no interest in pushing for a legal recognition of refugees in Thailand. With no other countries in the region, except Cambodia and the Philippines, being signatories to the Refugee Convention, it does not seem feasible that Thailand singlehandedly will address the main problem: the policy of not signing up to the 1951 Refugee Convention. An agreement among ASEAN countries to sign the Refugee Convention emerges as the resolution to push for. However, in the short run the prospect for such changes appears meagre. The reluctance to implement free movement of labour within ASEAN countries, in accordance with the principles of AEC, demonstrates that national interests override official commitments to regional cooperation and more unified immigration policies.

Three issues, all of them to do with the feeling of insecurity, appear to be very pressing: the arbitrary arrests, the long asylum seeking process and lack of agency. The fear of arrest influences every aspect of the lives of the refugees in the survey. It isolates the refugees and prevents them from working and generating a proper income that will make it possible to meet their living expenses, including health costs. It leads to a very sedentary life style resulting in poor physical and mental health condition. The arrests also deter parents from sending their children to a Thai government school and thereby deprive children their rights for education. Secondly, the very long time UNHCR spends on processing applications for asylum is a very traumatic period for the applicants. It prolongs the period the refugees must 
live under inhumane conditions and it contributes to their poor mental health status. The longer the refugees spend in Thailand, the more difficult it also becomes for families, and particularly for the children, to re-establish an "ordinary" life either in their resettled country or back in Pakistan. Thirdly, the absent of basic human rights and their social position as "victims" appeared to devoid the refugees the ability to take personal action.

Many interviewees appeared to have accepted the role of a "victim". They victimize themselves, allowing the absent of basic rights to relinquish them from the responsibility to act. This was observed in relation to personal control of their physical health and their children's education. People were concerned about access to health care, particularly for their children, but they showed indifference towards actively addressing their health status, as hardly any exercised. Though refugee children can attend a government Thai school, the option was hardly uptake. Though the fear of arrest may be very real, empirically there is very limited evidence that the police will arrest children on their way to school. It appears that possible arrests were a convenient excuse for not engaging with the Thai society. It was obvious that refugee families did not find it worthwhile to learn Thai. Their focus was purely on resettlement, while they at the same time analysed their current situation purely as victims that had forced them to put their lives on hold.

It is obvious that by safeguarding the human rights of the refugees their living conditions will improve. Making the refugee determination process more efficient and entitle the refugees with the right to apply for asylum within an acceptable time frame is acknowledged by UNHCR. They have already speeded up the application process. But when dealing with Thai authorities, a discussion from a human rights perspective on arbitrary arrests of urban refugees and the detrimental effects the arrests have on their living conditions may not be very fruitful. In the words of David Kennedy, it may be more beneficial to take up a more pragmatic attitude towards human rights. ${ }^{69}$ Advocating human rights for refugees and immigrants may fall for deaf ears in a country where political and civil rights overall are very restricted and where access to health and good education is not analysed from a human rights perspective, but overwhelmingly from a developmental stance. Not only refugees, but millions of migrant workers are without any medical protection while the rural population in many areas have inadequate access to proper health care. Their cases are not argued from the vantage point of human rights, but from the perspective of the responsibility of the developmental welfare state.

Kennedy ${ }^{70}$ talks about weighing the costs and benefits of human rights and points out that "the entire human rights vocabulary or movement suffers from a blindness or works an effect that we should count as a cost". NGO's working with refugees in Thailand are heavily populated with non-Thai nationals. The narrative of "Western" agitation for human rights do not resonate neither with the government nor big sections of the population. It may actually alienate decision makers, dismissing it as "Western thinking" and by so relinquish them from feeling any responsibility for an extremely marginal group in the society. Spurred by similar thinking, Thai nationals working for NGOs and faith organizations dealing with urban refugees have formed their own "umbrella organization" with the aim of promoting the living conditions of urban refugees. As one of the Thai officers said: "We know how to do it the Thai way", understood as being able to communicate with local authorities.

Advocating the human rights of the refugees may be discussed more productively within different narratives. The refugee policies of the Thai government appear incongruent. On the one hand, the Thai authorities arrest refugees randomly due to their undocumented status

69 D. Kennedy," The International Human Rights Movement: Part of the Problem?”, 2002, 15, Harvard Human Rights Fournal.

70 Ibid at 102. 
while the government simultaneously accepts the asylum-granting function of UNHCR. Naturally, the arrests can be seen as a function of a continuing punitive detention policy by the Thai government in order to deter people to seek refuge at UNHCR Thailand. But, the arrests may also be grounded in an ingrained culture of the police to enrich themselves rather than in any formulated policy to arrest refugees due to their illegal status. The issue is as such not human rights but rather the existing widespread culture of corruption within the Thai police force and the acceptance of the use of authority for personal gains. A practice which is recognized by the government to be a major obstacle to the development of the nation ${ }^{71}$. The argument rests on the "rule of law" rather than human rights, which will have a much wider appeal in the public sphere as well as with the government.

The physical and psychological living conditions the refugees endure clearly have an inimical effect on the physical and mental resources that the refugees can bring forth. Still, it is vital that the refugees within the constraints of their environment maintain a feeling of agency and personal responsibility for their daily lives and the upholding of human dignity. It was evident within the Pakistani community that Ahmadis had established a more organized community compared with Christians. More community activities took place, and it seems that more Ahmadi youngsters attended learning centres. The future prospects of the Ahmadi refugees appeared significantly more positive than for the Christians. To what extent it influenced their attitude is unestablished. But, in line with well documented theories on the positive impact of developing local community identification and support in order to manage own situation and reach out ${ }^{72}$, it appears that "grass root activities" and a more solid support of own community strengthened the Ahmadis' social contact with each other and their children's participation in some form of education. The degeneration of many Pakistanis' health status also illustrates the need of the refugees to take control of their own health condition. Therefore, NGOs should support the refugees in developing their communities and by so a responsibility for upholding a more meaningful life, that will support their self-esteem and capability to manage their life situation and their struggle for human rights.

\section{GONCLUSION}

The situation of the Pakistani refugees in Bangkok may reflect the conditions, which refugees in another ASEAN countries that have not signed the 1951 Refugee Convention, endure. These countries do not offer any legal protection of refugees. Hence, the refugees rely on the commitment of those countries to observe their human rights. However, as social progress in Thailand is not analysed within the perspective of personal rights but within a developmental stance, the human rights dialogue is lacking. Though the government informally acknowledges the presence of UNHCR asylum seekers and registered refugees, Thailand does not accept a responsibility for their wellbeing or the protection of their human rights. Rather, it upholds a punitive detention policy and allows the police to carry out arbitrary arrests that facilitates soliciting. The fear of arrest is the single most pernicious tribulation obstructing the lives of the refugees. It prevents them from upholding basic human rights and isolates them from participation in the society. However, considering the weak tradition for discussing human rights and the low status migrant workers otherwise have in the Thai society, the advocacy of the human rights of refugees may not resonate much with neither the

\footnotetext{
71 Pattarapong Niyomechat, Evaluation of Current Situation of Bribery and Corruption in Thailand, MPP Profesional Paper (University of Minnesota, 2015).

72 L. Platt, "Social activity, social isolation and ethnicity", 2009, 57:4, The Sociological Review 670.
} 
government nor the public. Strategically, it may be more beneficial to press for human rights by focusing on the harmful effect arbitrary arrest and the associated corruption and use of soliciting by the police has on the society as a whole. In the process of safeguarding the human rights of the refugees, it is also important that the refugees themselves refrain to see themselves purely as victims, but that they maintain their self-respect and some control over their situation, which will enable them to re-establish their lives either in a third country or back in Pakistan.

\section{REFERENCES}

Amara, A., H.; Aljunid, S., M., 2014, "Noncommunicable diseases among urban refugees and asylum-seekers in developing countries: a neglected health care need", Globalization and Health, 10:24.

Arendt, H., 1967, The Origins of Totalitarianism, London: George Allen and Unwin Ltd.

ASEAN, 2013," ASEAN Human Rights Declaration, and the Phnom Penh Statement on the application of the ASEAN Human Rights Declaration", The ASEAN Secretariat, http://www.asean.org/storage/images/ASEAN_RTK_2014/6_AHRD_Booklet.pdf

Bhabha, J., 2002,” Internationalist Gatekeepers? The tension Between Asylum Advocacy and Human Rights", Harvard Human Rights fournal, vol.15.

Bray, I., 2017," When can asylum applicants get a work permit", NOLO, http://www.nolo.com/legal-encyclopedia/asylum-applicants-work-permit-timing32297.html

Burnett, A.; Peel, M., 2001," Health needs of asylum seekers and refugees", British Medical Journal, 322(7285), pp. 544-547.

Collewet, L., 2012," Inhumane Detention Conditions in Bangkok?” Oxford Monitor of Forced Migration, 2:1.

Cornelius, W.A., 1982," Interviewing Undocumented Immigrants: Methodological Reflections Based on Fieldwork in Mexico and the U.S.", The International Migration Review, 16:2, Special issue: Theory and Methods in Migration and Ethnic Research, pp. 378 411.

Davies, S.E., 2008, International Refugee Law in South East Asia, Boston: Martinus Nijhoff.

Derks, A., 2013," Human Rights and (Im)mobility: Migrants and the State in Thailand", Journal of Social Issues in Southeast Asia, 28:2, pp. 216 -240.

Germany V., 2017," Working in Germany: getting a German Work Permit" Germanyvisa.org/working-germany-getting-german-work-permit/ (retrieved 25.6.2017).

Gerritsen, A., M.; Bramsen, I.; Deville, W.; Willigen, L.H.M.; Hovern, J., E.; Ploeg, H., M, v., 2006," Physical and mental health of Afghan, Iranian and Somali asylums seekers and refugees living in the Netherlands", Social Psychiatry and Psychiatric Epidemiology", 41;1, pp. $18-26$.

Gower, M., 2016," Should asylum seekers have unrestricted rights to work in the UK?", Briefing Paper, 1908, London: House of Commons Library.

Green, M.; Jacobsen, K., 2008," Invisible in Thailand: documenting the need for protection”, Forced Migration Review, 30.

Held, D., 2002," Laws of States, Laws of Peoples: Three Models of Sovereignty", Legal Theory, 8:1, pp. $1-44$.

Helton, A., 1989," Asylum and Refugee Protection in Thailand, International Fournal of Refugee Law, 1:1, pp. $20-47$

Jastram, k.; Achiron, M., 2001, Refugee Protection: A Guide to International Refugee Law, Office of the United Nations High Commissioner for Refugees, Geneva: Switzerland. 
Jaeger, G., 2003," Opening Keynote Address: The Refugee Convention at Fifty" in Selm, J.V. et al (eds) The Refugee Convention at Fifty, US: Lexington Books.

Kennedy, D., 2002," The International Human Rights Movement: Part of the Problem??, Harvard Human Rights foumal, vol. 15.

Kugelmann, D., 2010, "Refugees", Oxford Public International law, March 2010, Max Planck Encyclopedia of Public International Law

Laban, C.; Gernaat, H.; Komproe,I.; Schreuders, B.; Jong, J., 2004, "Impact of a long Asylum Procedure on the Prevalence of psychiatric Disorder in Iraqi Asylum Seekers in the Netherlands", The Fournal of Nervous and Mental Disease, 192:12, pp. 843-851.

Latif, E., 2010," Crisis, unemployment and psychological wellbeing in Canada", fournal of Policy Modelling, 32:4, pp. 520 -520.

Lauterpacht, E.; Bethlehem,D., 2003, The Scope and Content of the Principle of Non-refoulement in Feller,E.; Nicholson,F., (eds), Refugee Protection in International Law, UNCHR's Global Consultation on International Protection, Cambridge: Cambridge University Press.

Marfleet, P., 2007,", Forgotten"," Hidden": Predicaments of the Urban Refugee", Urban Refugees, 24:1.

MII (Ministry of Immigration and Integration), 2016," Aliens (Consolidation) Act of 25th. of June 2013", New to Denmark, Ministry of Integration and Immigration (Denmark), https://www.nyidanmark.dk/en-US/

Murshid, N., 2014, The Politics of Refugees in South Asia, Identity, resistence, manipulation, Abingdon: Routledge.

Niyoumchat, P., 2015, "Evaluation of Current Situation of Bribery and Corruption in Thailand. Perceptions of Government Officials and ordinary Citizens to the Situation", MPP professional Paper, The University of Minnesota.

Otter, V.D., 2007," Urban Asylum Seekers and Refugees in Thailand", Forced Migration Review, 28, 49-50.

Pernice,R.; Brook, J., 1996, "Refugees' and immigrants' mental health: association of demographic and post-traumatic factors", fournal of Social Psychology, 136, 51 1-519.

Phillomore, J.: Goodson L., 2006," Problem or Opportunity? Asylum Seekers, refugees, employment and Social Exclusion in Deprived Urban Areas", Urban Studies, 43:10, pp. $1715-1736$.

Platt, L. (2009). "Social activity, social isolation and ethnicity", The Sociological Review, 57:4, 670-702.

Save the Children, 2014," Pathways to a Better Future: A Review of Education for Migrant Children in Thailand", Save the Children in Thailand, Bangkok.

Selm, J., V.; 2003, Global Solidarity: Report of a Plenary Session in Selm, J.V. et al (eds) The Refugee Convention at Fifty, US: Lexington Books.

Silove, D.; Steel, Z.; Watters, C., 2000," Policies of Deterrence and the Mental Health of Asylum Seekers", Gournal of American Medical Association, 284:5.

Steel, Z.; Hey, M.; Silove, D.; et al, 2009," Association of Torture and other Traumatic Events with Mental Health Outcomes among Populations Exposed to Mass Conflict and Displacement, A systematic review and Mete-analysis". FAMA, 302:5, pp. 537 -549.

Theodossiou, I., 1998," The effects of Low-pay and unemployment on psychological wellbeing: A logistic regression approach", Fournal of Health Economics, 1, pp.85 -104.

Tribe, R., 2002," Mental Health of refugees and asylum-seekers", Advance in Psychiatric Treatment, 8:4, pp. $240-248$.

Vittaporn, S.; Boonmongkon, P., 2016," Thailand's health screening policy and screening of Burmese migrants with tuberculosis", Kasetsart Journal of Social Sciences, 37:3, pp. 170 174 . 
Government Gazette, Pattarapong Niyomechat, Evaluation of Current Situation of Bribery and Corruption in Thailand, MPP Profesional Paper (University of Minnesota, 2015)

1999," National Education Act of B.E. 2542 (1999)", The Government Gazette, 116:74a, August 1999, http://thailaws.com/law/t_laws/tlaw0165a.pdf

Human Rights Watch (HRW), 2012," Ad Hoc and Inadequate. Thailand's Treatment of refugees and Asylum Seekers", Human Rights Watch, US. https://www.hrw.org/sites/default/files/reports/thailand0912.pdf

Human Rights Watch (HRW), 2015, https://www.hrw.org/news/2015/09/16/thailandrelease-dozens-asylum-seekers.

International Justice Resource Center (IJRC), 2017, http://www.ijrcenter.org/refugee-law/

Tzu Chi, 2009," Tzu Chi Mission",

http://tw.tzuchi.org/en/index.php?option $=$ com_content\&view $=$ article\&id=293\&Itemid=28 $3 \&$ lang $=\mathrm{en}$

UNHCR, 2010," Convention and Protocol, Relating to the Status of Refugees", http://www.unhcr.org/en-us/protection/basic/3b66c2aa10/convention-protocolrelating-status-refugees.html

United Nations Human Rights, 2017, Office of the High Commissioner, http://www.ohchr.org/EN/ProfessionalInterest/Pages/CRC.aspx

Urban refugees. Org. (UR), 2015," Bangkok, Thailand", http://urbanrefugees.org/bangkok/

Jesper Kulvmann worked for many years in the health sector in Europe and on the African continent. In later years, he obtained an MSc in public health from London School of Economics and a Doctorate in social policy at University of Oxford. More recently, he has worked with integration of immigrants in Denmark. Currently, he is a lecturer at the Department of Social Administration, Thammasat University, Bangkok. His research interests include integration of immigrants, health economics and welfare state building. 